\title{
NUTRITIVE VALUE OF Gymnarchus niloticus AND Heterotis niloticus
}

\author{
Hassan Mohammed ADAM SULIEMAN1 ${ }^{\star \square}$ and Omeima Mohammed OMER ${ }^{2}$ \\ ${ }^{1}$ Department of Biology, College of Science, Yanbu Branch, Taibah University 039, Saudi Arabia Kingdom \\ ${ }^{2}$ Ministry of Agriculture, Animal Health and Irrigation, Khartoum, Sudan \\ 『Email: hassanadamus@yahoo.com; (D) ORCiD: 0000-00030773-8940 \\ supporting Information
}

\begin{abstract}
Major aspects of flesh nutritive value of Gymnarchus niloticus and Heterotis niloticus were studied in present research work. The body yield of $H$. niloticus followed the following decreasing order; fillet, head, skeleton, skin and viscera while in G. niloticus it is fillet, skeleton, head, skin and viscera. The fillet yield was found to be $46.9 \%$ in $\mathrm{G}$. niloticus and $42.3 \%$ in $\mathrm{H}$. niloticus. The length weight relationship, body weight and yield weight were significantly correlated in both species. Both species showed relatively high fat content. Significant negative correlations were found between moisture and ash in $\mathrm{H}$. niloticus and between moisture and fat in G. niloticus. On the basis of nutritional value (fat/protein) ratio of $H$. niloticus recorded 1:11.69, while the calculated caloric value of $\mathrm{H}$. niloticus was found to be $308.572 \mathrm{kcal} / \mathrm{g}$ and $253.474 \mathrm{kcal} / \mathrm{g}$ for G. niloticus. Present study provides a base line data on yield indices, chemical composition and nutritional value of these species and considered both species as a good source of food with high nutritive value.
\end{abstract}

Keywords: Body yield, Gymnachus niloticus, Heterotis niloticus, Nile Fishes, Nutritional value.

\section{INTRODUCTION}

The sustainable fin fish yield in Sudan is estimated to be around 100,000 tons/year from both fresh water and marine source (Henderson, 1975). This low yield best describes the fisheries of the Sudan as a small-scale activity mainly of subsistence type despite the presence of enormous water bodies. Although, Sudan is invested with expanded surface and underground water resources, and arable grounds that are appropriate to help to an enthusiastic catch fisheries and aquaculture industry (EI Magid and Elseed, 2008). Currently, capture fisheries activities are based on the River Nile and its tributaries, and the regional waters of Sudan on the Red Sea (El Magid and Elseed, 2008). Sudan produces a variety of plant crops, yet proteinaeous food stuff is particularly in short supply due to high price of red meat and export trade and has vast marine and inland resources that offer strong potential for sustainable fisheries and aquaculture (Menezes et al., 2019).

The rational solution to bridge this gap is to avail alternative sources of animal protein that could be characterized by cheapness and availability in different forms. The demand on fish has been growing over recent years although the actual production is reported as low as about $25 \%$ of estimated potential according Fisheries Research Centre Report in 1985. That is why we have a low level of fish production with a resultant low level of per capita fish consumption of about 1.0-1.5 kg/person/year (Fisheries Administration Department and Research Centre Report 1985, unpublished). Information on the meat quality and yield of fish in relation to its body weight is important in fish industry particularly in the marketing and processing in Africa in general and in the Sudan particularly (Sulieman et al., 2011). Also the contribution of fishery production and marketing sector in the household food security in the Red Sea State, Sudan studied by Hamza et al. (2017). The results showed that $\mathbf{8 5 . 4 \%}$ of the enterprises are managed by their owners while $\mathbf{8 . 5 \%}$ hire their relatives with $85 \%$ of enterprises in fishery sector were depends on self-financing.

Many authors they studied Information on the meat quality, nutritive value and yield of fish in relation to its body weight which is important in fish industry particularly in the marketing and processing sectors (Deng et al., 2016). The different yields of fillets and edible portion meat permit some flexible attempt to investigate the actual measure of fish tissue consumed in certain countries. The remaining inedible tissue is transferred with the bones, offal and perhaps skin to fish meal factory, when it might contribute indirectly to human nutrition (FAO, 1989). Little work was carried out on the determination of fish body characteristics in Africa in general and in the Sudan particularly. The proximate composition and microbial load of smoke-dried Gymnarchus niloticus, the gross chemical composition of some traditionally processed Nile fishes from Sudan also was studied by Ahmed et al. (2020), and Ricketts and Oyero (2021). Result of the nutritive quality and proximate analysis of these studied fishes were showed different variations result. While proximate composition, energy value, amino acid profile, and protein quality of the muscle tissue of studied fish species from Asia availed a high quality as stated by Pyz-Łukasik and Paszkiewicz (2018). Since fish form an important source of human food, the knowledge of the chemical composition is an important aspect of the fish quality as it influences both the keeping quality and technological characteristics of the fish (Huss, 1988; Tesfamichael and Elawad, 2016). 
This knowledge will probably enhance understanding of the pattern of choice of species, facilitate introduction of small scale industries and production of fish meal. Moreover, utilization of all parts of fish directly (fresh) or indirectly as fish feed for domestic animals can contribute largely to shorten the gap in feed supply and minimize the hazardous waste. The objectives of this study were to provide chemical and physical information on Gynmarchus niloticus and Heterotis niloticus with a view of determining their nutritive value.

\section{MATERIALS AND METHODS}

\section{Samples}

Twenty Nine specimens of Gymnarchus niloticus (58-89 cm in total length and 600-2050 $\mathrm{g}$ in body weight) and twenty-three of Heterotis species (36.6 $-62.5 \mathrm{~cm}$ in total length and $390-2550$ grams body weight) were collected from Nile River $45 \mathrm{Km}$ south of Khartoum City and used for this study.

\section{Body weight characteristics}

All 29 of G. niloticus and 23 of H. niloticus of studied fresh samples were used to determine the yield indices for each specimen. The weight of the head, viscera, fillet, skin and skeleton were determined in grams and related to total body weight as percentage (Table 1).

\section{Chemical analysis}

The gross chemical composition (Moisture, Protein, Fat and Ash of minced fillet were determined according to standard and protocol methods of Horwitz (1982). All the proximate investigations were completed in triplicate and detailed in percent.

\section{Statistical analysis}

To quantify the relationship between the total length and total body weight, total weight and weights of different parts of body fillet, head, skeleton, viscera and skin), and the relation between major chemical components for both species, simple linear regression analysis were performed according to Gomez and Gomez (1984). Also, all analysis were carried out using statistical package for social science (SPSS, Version 10).

\section{RESULTS AND DISCUSSION}

The body yield of the major body parts for $H$. niloticus and G. niloticus was given in Tables 1 and 2, and Figure 1 , respectively. The following by-products (inedible parts, Table 1 and Figure 1 of the two species recorded up to $50 \%$, which can be used as animal feeds especially in fish culture and poultry feeding. Proper utilization of such by-products in major fish markets can contribute in solving waste disposal related problems and unemployment. Many authors, reported that the fillet waste of the Nile fish processing plants include skeletons with adhering fish flesh, heads, guts and skins. Some filleting plants process the waste by themselves (drying of swim bladders as delicacy, extraction of oil, production of fishmeal (Ahmed et al., 2010). While others sell the skeletons and heads to local women processors for processin (Sulieman et al., 2011). These include extraction of Nile fish oil, frying of frames, drying of fish skins for use as fuel. The liability of these processed by - product to attack and microbial infection should not be excluded (Mohammed, 2003).

Table 3 and Figure 2 show moisture content, which does not have nutritive value, but it is important in describing food composition and its nutritive value (Pike and Brown, 1967). Both species' moisture levels (78.2 \pm 2.6 and $79.3 \pm 0.7$ \% for $\boldsymbol{H}$. niloticus and G. niloticus respectively) are within the range reported for Nile fishes by Mahmoud (1977); Babiker (1981) and Ahmed et al. (2010). When it came to protein content, the chemical analysis revealed that each species had a protein content of 61.25 .8 and 67.32 .12 percent, which was expected for a dry product. The results were compared to the range observed for other Nile fish species. Ahmed et al. (2010), reported that the protein content was 15-24\% for wet flesh. Sulieman and James (2011), reported that the protein content for Tilapia nilotica, Synodontis, Barbus bynnie, Bagrus bayad and Bagrus docmac, ranged between 14 to 23\%. The discrepancy in protein level may be due to collection of fish after a period of low food availability and/or spawning activity and seasonal variation effectiveness in the chemical composition of fish flesh (Nargis, 2006).

The mean value of fat content was higher in H. niloticus $(12.5 \pm 6.7)$ than in G. niloticus $5.7 \pm 5.7)$. Babiker (1981) studied more than twenty species from Nile, he stated that a high relative proportion of tissues was fat and is a negative feature but gives a higher energy yield. The ratio of fat to protein is an indication of the nutritional value of the fish flesh. According to Babiker (1981) with respect to Nile fishes, the catfishes possess the highest calculated caloric value. This is probably due to its high fat content of the edible tissues.

\begin{tabular}{|c|c|c|c|c|c|c|c|c|c|}
\hline Species & $\begin{array}{l}\text { Total Wt. } \\
\text { (g) }\end{array}$ & $\begin{array}{c}\text { Total } \\
\text { length }(\mathrm{cm})\end{array}$ & $\begin{array}{l}\text { Fillet } \\
(\%)\end{array}$ & $\begin{array}{c}\text { Viscera } \\
\text { (\%) }\end{array}$ & $\begin{array}{l}\text { Head } \\
(\%)\end{array}$ & $\begin{array}{c}\text { Skeleton } \\
\text { (\%) }\end{array}$ & $\begin{array}{c}\text { Skin } \\
(\%)\end{array}$ & $\begin{array}{c}\text { Edible } \\
\text { Parts (\%) }\end{array}$ & $\begin{array}{l}\text { Inedible } \\
\text { Parts (\%) }\end{array}$ \\
\hline $\begin{array}{l}\text { Heterotis } \\
\text { niloticus }\end{array}$ & $1203.3+512.9$ & $49.3 \pm 6.1$ & $42.3 \pm 21.8$ & $8.0 \pm 3.8$ & $20.3 \pm 7.2$ & $15.4 \pm 5.8$ & $12.2 \pm 7.1$ & $42.3+21.8$ & $55.9+23.9$ \\
\hline $\begin{array}{l}\text { Gymnarchus } \\
\text { niloticus }\end{array}$ & $1354.6+510.2$ & $76.9 \pm 9.6$ & $46.9 \pm 20.6$ & $7.6 \pm 2.9$ & $15.2+4.4$ & $17.9 \pm 8.4$ & $9.3 \pm 5.6$ & $46.9+20.6$ & $52.0 \pm 21.3$ \\
\hline
\end{tabular}


Table 2 - Linear regression between total body weight and different body parts of Heterotis niloticus and Gymnarchus niloticus after logarithmic transformation of variables $(\log 10(X))$

\begin{tabular}{lcc|cc}
\multirow{2}{*}{ Parameter } & \multicolumn{2}{c|}{ Regression equation } & \multicolumn{2}{c}{ Correlation coefficient } \\
\cline { 2 - 5 } & Heterotis niloticus & Gymnarchus niloticus & Heterotis niloticus & Gymnarchus niloticus \\
\hline Log T. wt./fillet & $\mathrm{Y}=1289.9 \times-3417.5$ & $\mathrm{Y}=1473.8 \times 3928.9$ & 0.897 & 0.955 \\
Log T. wt./head & $\mathrm{Y}=399.5 \times 971.5$ & $\mathrm{Y}=325.3 \times 801.9$ & 0.849 & 0.793 \\
Log T. wt./skeleton & $\mathrm{Y}=320.4 \times 790.3$ & $\mathrm{Y}=585.3 \times 1570.3$ & 0.846 & 0.919 \\
Log T. wt./skin & $\mathrm{Y}=4054.5 \times 1087.8$ & $\mathrm{Y}=312.9 \times 843.6$ & 0.868 & 0.742 \\
Log T. wt./viscera & $\mathrm{Y}=192.3 \times 488.9$ & $\mathrm{Y}=123.9 \times 280.6$ & 0.856 & 0.551 \\
\hline T. wt. = Total weight; Log = logarithmic transformation of variables (Log10(x). & &
\end{tabular}

Table 3 - Proximate analysis and their correlation for Heterotis niloticus and Gymnarchus niloticus

\begin{tabular}{lcc} 
Components & Heterotis niloticus & Gymnarchus niloticus \\
\hline Moisture & $782 \pm 2.6$ & $79.3 \pm 7.1$ \\
Ash & $5.5 \pm 1.1$ & $4.2 \pm 1.3$ \\
Fat & $12.5 \pm 6.7$ & $5.8 \pm 5.7$ \\
Protein & $61.2 \pm 5.8$ & $67.3 \pm 2.1$ \\
Calculated Caloric Value & $308.572 \mathrm{Kcal} / \mathrm{g}$ & $253.47 \mathrm{Kcal} / \mathrm{g}$ \\
Fat: Protein & $1: 4.89$ & $1: 11.69$ \\
\hline
\end{tabular}

Table 4 - Energy values as contributed by protein, fat, moisture and ash in Heterotis niloticus and Gymnarchus niloticus

\begin{tabular}{llcc} 
Correlates & The regression equation & R & Level of significant \\
\hline Protein/fat & Fat $=4.1 \times 2.8$ protein & 0.523 & $*$ \\
Ash/fat & Fat $=3.88-7.8$ ash & 0.611 & $*$ \\
Moisture/Fat & Fat $=331.6-4.0$ moisture & -0.096 & $*$ \\
Moisture/Ash & Ash $=111.1 \pm 1.32$ moisture & -0.205 & $*$ \\
Protein/ash & Ash $=63.11 \pm 4.01$ protein & 0.317 & $*$ \\
Moistures/Protein & Protein $=34.46 \pm 8.44$ moisture & 0.282 & $*$ \\
* Significant at $(\mathrm{P} \leq 0.05)$. & & &
\end{tabular}

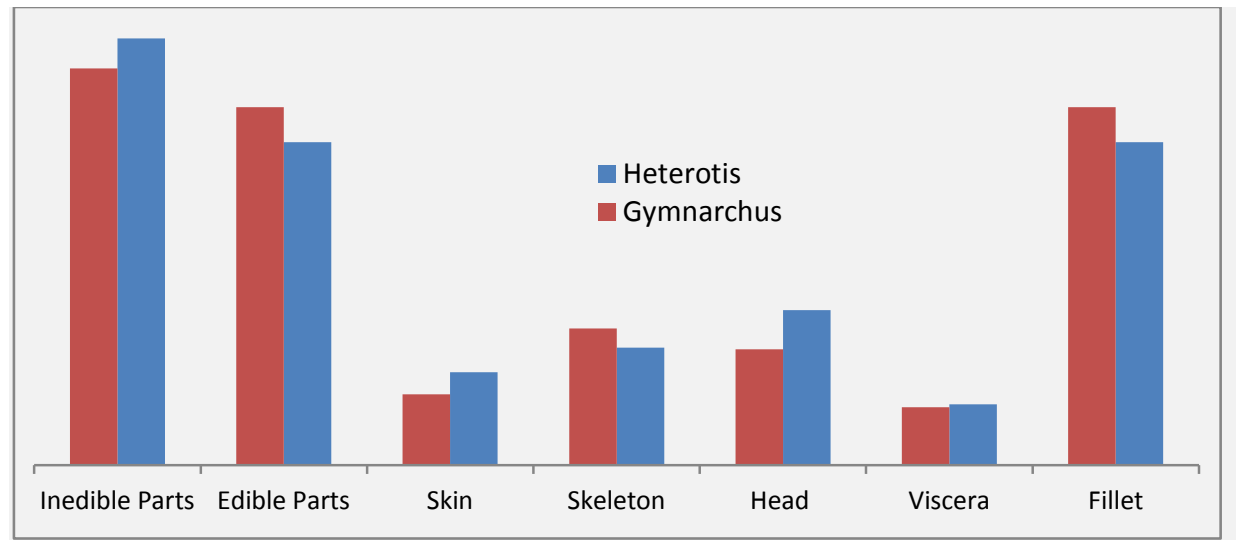

Figure 1 - The mean yields of different body parts in Heterotis niloticus and Gymanrchus niloticus

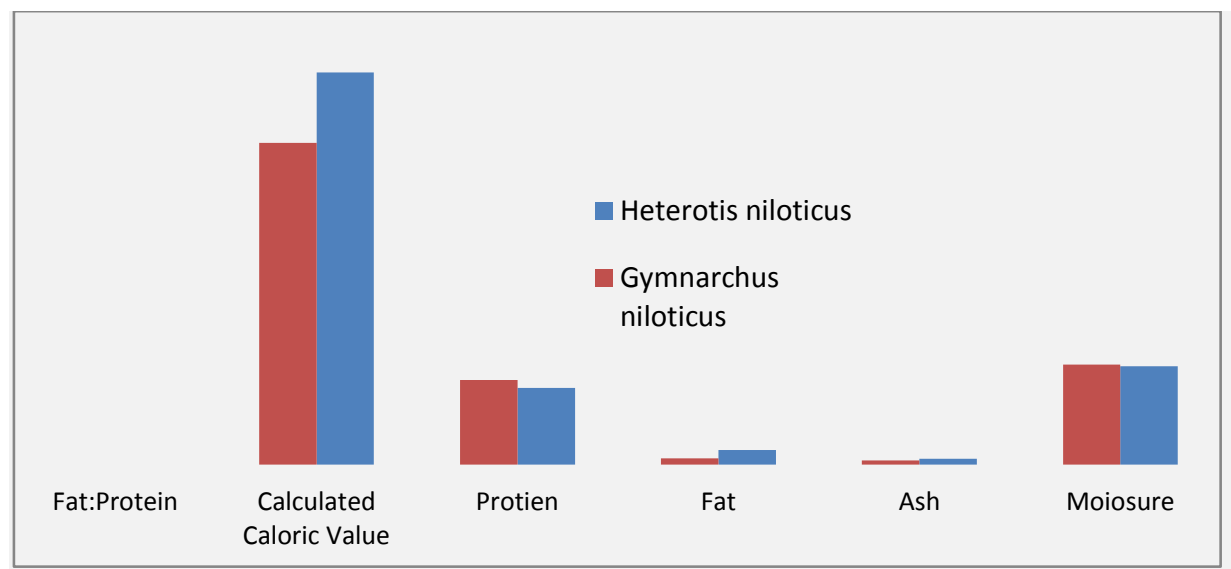


The energy value of studied fishes (Table 4) as contributed by protein and fat has been discussed as a measure of nutritional condition of animal by Pike and Brown, (1967), Mahmoud (1977), and Adeyeye and Adamu (2005) used 9.45 $\mathrm{Kcal} / \mathrm{g}$ for fat and $5.65 \mathrm{Kcal} / \mathrm{g}$. For protein Mahmoud (1977) used $9.45 \mathrm{Kcal} / \mathrm{g}$ for fat and $4.1 \mathrm{Kcal} / \mathrm{g}$ for protein; FAO recommended $4.2 \mathrm{kcal} / \mathrm{g}$ for fat and for protein $9.02 \mathrm{Kcal} / \mathrm{g}$ for fat. However, the ideal way to determine the energy value of fish is by the use of caloric bomb. While for the nutritive value a well-planned feeding experiment is to be carried out.

Some fish species possess high ratio of fat although not acceptable by most consumers. Fish sandwich shops and restaurants owners favour for fourth and third class fish. In this respects Auchenoghanis sp., Tetraodon sp. and Malapterurus can be cited as typical examples. Such type of fishes can contribute much in solving the problem of energy deficiency and malnutrition in the rural area (usually for away from the Nile or the Red Sea) as suggested by Babiker (1981). These needs effort to introduce eating of his and/or it's a product in to the food culture of these people.

Ash content as a nutrient element is important in metabolic process but have little value as food item. Aremu and Ekunode (2008) and Olanrewaju et al. (2016) investigated to determine the nutritive value, the nutritional evaluation and functional properties of fish (Clarias Lazera) were found that, the crude protein, crude fat, carbohydrate, moisture and total ash contents $73 \%, 8.3 \%, 2.5 \%, 7.5 \%, 8.6 \%$ respectively. These results showed some variations and disagree and agree with many researchers. In the present investigation ash content for $\boldsymbol{H}$. niloticus was $5.4 \%$ and for G. niloticus was 4.23\%. The ash content varies among the different species of the Nile fishes as reported by Adeyeye and Adamu (2005). The result of ash reported by $1.19 \%$ and $0.52 \%$ in Oreochromis niloticus from different locations and $0.85 \%$ on wet weight basis. Ahmed et al. (2010) reported $25.5 \%$ ash content in. C. niloticus. lazera and in Alestes dentex.

One can conclude that, the study provides a base line data on yield indices, chemical composition and nutritional value of these species and considered both species as a good source of food with high nutritive value for human consumption.

\section{DECLARATIONS}

\section{Corresponding author}

E-mail: hassanadamus@yahoo.com

\section{Authors' contributions}

All authors participated in this research equally.

\section{Competing interests}

The authors declare that they have no competing interests.

\section{Ethical Regulation}

The present research work does not contain any studies performed on animals/humans subjects by any of the authors.

\section{REFERENCES}

Adeyeye E and Adamu A (2005). Chemical composition and food properties of Gymnarchus niloticus (Trunk fish). Bioscience Biotechnology Research Asia, 3(2): 265-272. Link: http://www.biotech-asia.org/?p=4528

Ahmed EO, Ali ME, Kalid RA, Taha HM and Mahammed AA (2010). Investigating the quality changes of raw and hot smoked Oreochromis niloticus and Clarias lazera. Pakistan Journal of Nutrition, 9(5): 481-484. DOI: https://dx.doi.org/10.3923/pjn.2010.481.484

Ahmed RA, Mahmoud ZN and Hammad N (2020). The gross chemical composition of some traditionally processed Nile fishes from Sudan. International Journal of Fisheries and Aquatic Studies, 8: 196-199. link: https://www.fisheriesjournal.com/archives/2020/vol8issue3/PartC/8-2-70-161.pdf

Aremu $\mathrm{M}$ and Ekunode 0 (2008). Nutritional evaluation and functional properties of Clarias lazera (African catfish) from river Tammah in Nasarawa State, Nigeria. American Journal of Food Technology, 3(4): 264-274. DOI: https://dx.doi.org/10.3923/ajft.2008.207.213

Babiker M (1981). Dietary Nile fishes: A reclassification according to nutritional merit. Sudan Notes and Records, 62: 161-170. Link: https://www.africabib.org/rec.php?RID=188817824

Deng 00, Mohamed AH, Agib M, Fl-faki F and Ali M (2016). Comparative studies on nutritive value of wild and farmed African catfish Clarias gariepinus. International Journal of Fisheries and Aquatic Studies, 4(3): 327-329. https://www.fisheriesjournal.com/archives/?year=2016\&vol=4\&issue=3\&part=E\&Articleld=763

EI Magid MAA and Elseed SMH (2008). Fisheries Resources of Sudan. Elliott J (1976). Body composition of brown trout (Salmo trutta L.) in relation to temperature and ration size. The Journal of Animal Ecology, 75(1): 273-289. DOI: https://doi.org/10.2307/3779

FAO (1989). Yield and nutritional value of the commercially more important fish species. FAO Fisheries Technical Papers 309: 1187. DOI: http://www.fao.org/docrep/003/t0219e/t0219e01.htm 
Gomez KA and Gomez AA (1984). Statistical procedures for agricultural research: John Wiley \& Sons. Link: https://www.wiley.com/en-us/Statistical+Procedures+for+Agricultural+Research\%2C+2nd+Edition-p-9780471870920

Hamza M, Alhasseen I and Mohamed S (2017). Contribution of fishery production and marketing sector in the household food security in the Red Sea State, Sudan. American Scientific Research Journal for Engineering, Technology, and Sciences (ASRJETS), 31(1): 176-182. Link: http://asrjetsjournal.org/index.php/American_Scientific_Journal/article/download/2908/1133

Henderson H (1975). The fisheries of the reservoirs of Central Sudan, Cairo, FAO Report. Near East Reg. FAO, Rome. link: https://www.fao.org/3/t0361e/T0361E09.htm

Horwitz W (1982). Evaluation of analytical methods used for regulation of foods and drugs. Analytical Chemistry, 54(1): 67-76. DOI: https://doi.org/10.1021/ac00238a002

Huss HH (1988). Fresh fish-quality and quality changes: a training manual prepared for the FAO/DANIDA Training Programme on Fish Technology and Quality Control: Food \& Agriculture Org. Link: https://books.google.com.sa/books?isbn=9251023956

Mahmoud Z (1977). Studies on Meat Quality of some Nile Fish. M. Sc. Thesis, Department of Zoology, University of Khartoum, Sudan. Link: http://api.uofk.edu:8080/api/core/bitstreams/1312466a-e7c5-4090-b72e-920d6a8b798f/content

Menezes A, Fersoy H and Fantinet M (2019). FAO supports Sudan fisheries and the aquaculture sector. FAO Aquaculture Newsletter, 60: 27-27. Link: https://www.fao.org/neareast/news/view/en/c/1178814/

Mohammed AEIE (2003). Post-harvest hazards at Khartoum and Almourda Fish markets. University of Khartoum. Link: http://khartoumspace.uofk.edu/bitstream/handle/123456789/10588/Postharvest\%20hazards\%20at\%20Khartoum\%20and\%20Almourda.pdf?sequence $=1$

Nargis A (2006). Seasonal variation in the chemical composition of Body flesh of Koi Fish Anabas testudineus (Bloch)(Anabantidae: Perciformes). Bangladesh Journal of Scientific and Industrial Research, 41(3): 219-226. doi: http://dx.doi.org/10.3329/bjsir.v41i3.292

Olanrewaju AN, Kareem OK and Shobowale JO (2016). Proximate and mineral compositions of Schilbe mystus (Linne 1758) and Heterotis niloticus (Cuvier 1829). Animal Research International, 13(3): 2554-2561. link: https://www.ajol.info/index.php/ari/article/view/149943

Pike RL and Brown ML (1967). Nutrition: an integrated approach. Nutrition: an integrated approach. DOI: https://www.cabdirect.org/cabdirect/abstract/19681406282

Pyz-Łukasik R and Paszkiewicz W (2018). Species variations in the proximate composition, amino acid profile, and protein quality of the muscle tissue of grass carp, bighead carp, siberian sturgeon, and wels catfish. Journal of Food Quality, 2018: Article ID 2625401. DOI: https://doi.org/10.1155/2018/2625401

Ricketts A and Oyero J (2021). Nutritive quality and microbial assessment of stored smoked dried Gymnarchus niloticus Cuvier, 1829. Journal of Research in Forestry, Wildlife and Environment 13(2): $143-151 . \quad$ Link: https://www.ajol.info/index.php/irfwe/article/view/211998

Sulieman HA, Ali M and Tibin M (2011). Filleting yield and physical attributes of some fish from Lake Nubia. Online Journal of Animal and Feed Research 1(6): 412-416. https://ojafr.com/main/attachments/article/80/0JAFR,\%20A55,\%20412416,\%202011.pdf

Sulieman HA and James GK (2011). A comparative studies on the chemical and physical attributes of wild farmed Nile tilapia (Oreochromis niloticus). Online Journal of Animal and Feed Research 1(6): 407-411. Link: https://ojafr.com/main/attachments/article/80/OJAFR,\%20A54,\%20407-411,\%202011.pdf

Tesfamichael D and Elawad AN (2016). Sudan. The Red Sea Ecosystem and Fisheries. Springer, pp.37- 48. DOI: https://doi.org/10.1007/978-94-017-7435-2 